\title{
Two social exchanges and service personnel's internal service behavioural intention at international tourism hotels
}

DOI 10.1515/ejthr-2016-0017

received 20 November, 2015; accepted 5 May, 2016

Abstract: Hospitality is a service industry in which team cooperation and assistance among the co-workers is necessary. Scholars have found that salary or benefits by themselves are not sufficient to motivate employees' internal service intention and attitude. The norm of reciprocity in which the individuals' intention results in active behaviour that is driven by the desire to obtain rewards has rarely been applied in the field of hotel internal service. In this study, we used the theory of planned behaviour (TPB) to investigate the effects of leader-member exchange (LMX) and co-worker exchange on internal service behavioural intention and its causes, that is, attitude, subjective norms, and perceived behavioural control. In this study, we chose frontline professional service personnel from 30 international tourist hotels in Taiwan as research subjects and collected 684 valid questionnaires for statistical analysis. The results showed that LMX and co-worker exchange significantly affected the internal service behavioural intention and were significantly correlated with the causes of internal service behaviour intention, that is, attitude, subjective norms, and perceived behavioural control. The results of this study should provide practical and theoretical assistance guidance for the rapidly growing domestic hospitality industry, in terms of increasing service competitiveness and facilitating the strategic planning of human resource management.

\footnotetext{
*Corresponding author: Wen-Jung Chen, Hospitality Management Department, De Lin Institute of Technology, No. 1, Lane 380, Qingyun Rd., Tucheng Dist, New Taipei City, 236 Taiwan, R.O.C., Tel: 8862-2273-3567 \#369, Fax: 886-2-2273-4426, Email: wenjung515@ gmail.com
}

Keywords: Social Exchange, Theory of Planned Behaviour, Internal Service Behavioural Intention, Hospitality Industry

\section{Introduction}

Trends in global tourism and leisure have resulted in the annual doubling of the number of tourists over the past 5 years, and the hospitality industry has contributed significantly to the global service economy (Ma and Qu, 2011). Statistics from the Tourism Bureau of Taiwan show that the number of tourists is expected to reach 9 million in 2014 and that the number of hotels in Taiwan has grown at an even more rapid rate, reaching over 7000 in mid-2014. The hospitality industry is facing increasingly fierce competition and is realizing that satisfying the diverse demands of customers and keeping up with continuously emerging innovations within the industry requires the co-workers to cooperate with and assist each other to provide better quality service and create satisfying brands (Chen, 2013).

Internal service is an internal environment that results from the co-workers that share a customer support mentality. Within this concept, the employees are considered to be internal customers and other supporting personnel, including managers and other service supporting personnel, are considered to be internal service providers. In such an environment, good internal service benefits the external customer service, thereby affecting the performance of the entire company (Large and König, 2009). Wildes and Parks (2005) used the restaurant service personnel as research subjects and found that when employees encountered good internal service, their desire to leave decreased and they achieved a sense of satisfaction and a sense of identity that enhanced their work quality and performance. The theory of planned behaviour (TPB) that was introduced by Ajzen in 1985 is a comprehensive and broad framework for predicting certain types of 
individual behaviours. According to this theory, both perceived behavioural control and behavioural intention are predictable. Behavioural intention is collectively determined by the attitude, subjective norms, and perceived behavioural control that are associated with a specific behaviour. That is, the more favourable are an individual's attitude and the subjective norms of a certain behaviour and the stronger is the perceived behavioural control, the stronger is the individual's desire to demonstrate such behaviour (Ajzen, 1985, 1991). However, most studies on TPB have investigated the individuals' knowledge sharing behaviour. Examples are Johnny and Bolloju (2005) and Bock, Zmud, Kim, and Lee (2005). TPB has very rarely been applied to the field of internal service of hotel employees.

Social exchange is a voluntary action that individuals demonstrate when they expect to obtain rewards from elsewhere (Kamdar and Van Dyne, 2007). From the perspective of social exchange, employees who expect support and assistance from their co-workers must also provide support and assistance to their co-workers. In addition, workers who want to be respected and valued must demonstrate a behaviour that benefits the organization or their co-workers (Wu and Chen, 2015; Cho and Johanson, 2008). Leader-member exchange (LMX) is a type of exchange that has been attracting the most attention among social exchange premises (Organ, Podsakoff, and MacKenzie, 2006). Within LMX, employees in formal work settings who hope to obtain rewards from their managers, such as good evaluations, raises, promotions, or favourable work arrangements, demonstrate behaviour that is beneficial to the organization and is consistent with or even above what the company and its managers require. However, Bettencourt and Brown (1997) found that many service industries, such as hospitability, require a service environment in which the co-workers assist each other and that involves team cooperation. Therefore, in the processes involving highly intimate interactions, employees who wish to obtain rewards from co-workers, such as mutual assistance and care, demonstrate behaviour that meets or exceeds co-workers' expectations, which is the premise of co-worker exchange.

Hotel service relies highly on mutual cooperation and cooperation among colleagues to provide superior service. However, the TPB has rarely been applied to the field of hotel service. Thus, in this study, we use the TPB to investigate the effects of LMX and co-worker exchange on internal service behavioural intention and its causes, that is, attitude, subjective norms, and perceived behavioural control. In this study, we developed an effect model of the internal service of employees in the hospitality industry that provided practical and theoretical guidance to the rapidly growing domestic hospitality industry in terms of increasing service competitiveness and facilitating the strategic planning of human resource management.

\section{Literature review}

In this study, we formulate a correlation model of the factors that affect hotel employee internal service, that is, LMX, co-worker exchange, and the TPB, which are individually considered low in priority.

\subsection{Leader-member exchange (LMX)}

In the studies of organization leadership, scholars have often used the theory of LMX to explain the process and results of leadership. This theory was first introduced by Graen et al. (Dansereau, Graen, and Haga, 1975; Graen and Cashman, 1975). Traditional leadership theory emphasizes the individual characteristics of leaders, leadership circumstances, and the interaction between these 2 factors. LMX differs from other traditional leadership theories in that the social exchange view is used to model the process by which leaders exert their authority to develop exchange relationships with their subordinates. LMX emphasizes the dynamic relationship between leaders and members (Dansereau, et al., 1975; Graen and Cashman, 1975; Graen, Liden, and Hoel, 1983). Within this theory, leaders often have a few close subordinates (which are called internal groups), such as assistants, aides, or consultants, with whom they maintain good formal and informal relationships, in terms of trust, interaction, and support, while establishing different interaction relationships with other subordinates (which are called external groups). These 2 types of relationships indicate the quality of leader-member interaction relationships.

In internal group interaction relationships, close relationships and mutual trust between the leader and some of his subordinates (Dansereau et al., 1975; Liden and Graen, 1980) often results in the leader giving these subordinates favourable rewards, such as interesting work assignments, increased authority and power (Bauer and Green, 1996), access to inside information, allowing subordinates to participate in decision-making, promotions, and special benefits. Accordingly, it is often assumed that members in these types of relationships spend more time, take on more administrative responsibilities, and make increased efforts to achieve goals (Dansereau et al., 1975; Liden and Graen, 1980; Yukl, 1994) in response to the high 
rewards given by the leader. Thus, this type of interaction relationship has high quality. In leaders' interaction with external groups, frequently because of time limitations, leaders can only use legitimate coercive power and limited rewarding power to exchange resources with subordinates with whom leaders often have difficulties establishing good relationships.

\subsection{Co-worker exchange}

Ma and $\mathrm{Qu}$ (2011) found that in the hospitality industry, the co-workers must cooperate with each other to deliver high-quality service. Within the concept of co-worker exchange, the co-workers interact socially both with managers or leaders and other co-workers. The concept of co-worker exchange is based on the theory of social exchange. According to the theory of social exchange, employees who perceive a high degree of organizational support have positive attitudes and behaviours toward giving back to the organization (Eisenberger, Fasolo, and Davis-LaMastro, 1990). In the co-worker exchange, the employees believe that co-workers are willing to assist them in completing their work in terms of knowledge sharing, encouragement, and assistance (Susskind, Kacmar, Borchgrevink, 2003). To obtain the co-workers' support and assistance, employees contribute the same. Many studies have shown that employees who perceive sufficient support and assistance from their co-workers feel that they have more work resources available to them to relieve pressure, solve customer problems, and improve service performance, which decreases their desire to leave their jobs. (Cho and Johanson, 2008; Tsai, Chen, and Cheng, 2009). The co-worker interaction is a commonly used work model in the hospitality industry, but co-worker exchange has rarely been applied to the hotel service studies.

\subsection{Theory of planned behaviour (TPB)}

The study of human behaviour considers psychological processes to describe social norms. Many scholars have found that certain behavioural dispositions can effectively predict and explain behaviours that are demonstrated by human beings (Ajzen, 1988; Campbell, 1963; Sherman and Fazio, 1983). Among these scholars, Ajzen (1985) developed the TPB in which behavioural disposition is used to predict human behaviour.

TPB is an extension of the theory of reasoned action that was developed by Fishbein and Ajzen (1975).
According to the theory of reasoned action, belief can affect an individual's overall attitude toward a certain subject. This attitude then affects the individual's intention, which further determines his behaviour towards the subject. Among these factors, intention is the subjective likelihood that an individual performs a certain act rather than an actual behaviour. Predicting behaviour from intention has certain limitations, because behaviour is purely voluntary. That is, the individual can decide whether or not to demonstrate such behaviour. However, certain behaviour can be restricted by some non-motivating factors such as time, money, skills, and cooperation with others (Ajzen, 1985). Thus, to improve the predictive power of the theory of reasoned action, Ajzen (1985) added perceived behavioural control and used TPB to explain real behaviour.

Within the TPB model, TPB and behaviour intention are both predictable behaviours, and behavioural intention is determined by an individual's collective attitude toward the behaviour, subjective norms, and perceived behavioural control (Ajzen, 1985, 1991). According to the TPB, an individual's attitude towards certain behaviour is his favourable or unfavourable evaluation of certain behaviour. An individual's attitude is determined by the intensity of his belief that certain results are caused by certain behaviours and the extent of his desire for these results (Eagly and Chaiken, 1993). Taylor and Todd (1995) state that the more positive an individual's attitude towards a specific behaviour is, the more positive and stronger is this individual's intention for such a behaviour and vice versa. Subjective norms consist of social pressure that the individual perceives to determine whether to demonstrate certain behaviours, the intensity of his belief that important reference individuals or groups will recognize certain behaviours, and the extent to which the individual is willing to obey significant reference subjects (Bock, Zmud, Kim, and Lee, 2005). Many studies have also confirmed that subjective norms affect an individual's behavioural intention (Han, Hsu, and Sheu, 2010; Rhodes and Courneya, 2003; Taylor and Todd, 1995; Tonglet, Phillips, and Read, 2004). Perceived behavioural control refers to an individual's perception of whether the resources and opportunities required by certain behaviour are easy to obtain and the effects of related past experience, second-hand information, his experience of the people around him, and the potential difficulties he may encounter (Taylor and Todd, 1995). There are 2 components of perceived behavioural control: facilitating conditions and self-efficacy. The first component reflects the extent to which an individual can obtain resources, such as time, money or other obtainable resources, that are required to 
demonstrate certain behaviours. The second component reflects the extent to which the individual believes in his or her ability to demonstrate certain behaviours (Conner and Armitage, 1998). Studies have confirmed that perceived behavioural control has significant positive effects on behavioural intention (Fitch and Ravin, 2005; Kidwell and Jewell, 2003; Terry and O'Leary, 1995).

Internal service is the provision of service to other units or individuals within an organization (Billy, Pearl, Gail, and Skip, 2006). Boshoff and Mels (1995) found that employees and departments are both users and providers of service. This internal service affects the demonstration and effects of services to outside customers (Large and König, 2009). Given that the hotel service requires team cooperation and mutual support among co-workers to create and deliver services (Chen, 2013), the below mentioned hypothesis based on the TPB was proposed:

H1: The attitude of hotel service personnel towards internal service, their subjective norms, and perceived behavioural control have positive effects on internal service behavioural intention.

\subsection{LMX, co-worker exchange, internal service behavioural intention and its causes}

In social exchange theory, the norm of reciprocity is commonly used to explain bilateral behavioural relationships (Sierra and McQuitty, 2005). The application of LMX to management behaviour requires that the effective leaders are skilled at organizing resources, establishing and maintaining good exchange and interaction relationships with subordinates in the process of allocating resources, and in providing subordinates with extra benefits and opportunities. Consequently, in the process of mutual benefit and reciprocity, leaders can ask subordinates to take on more responsibilities in exchange for extra benefits, thereby increasing the leader's influence (llies, Nahrgang, and Morgeson, 2007). Li, Sanders, and Frenkel (2012) used luxury hotels in mainland China as research subjects and found that LMX had positive effects on employees' investment in work and their willingness to assist and support each other. Kim, O'Neill, and Cho (2010) investigated the reasons for mutual cooperation among workers in the hospitality industry and found that LMX encouraged the workers to voluntarily provide service and assistance to obtain rewards or positive responses. Thus, we proposed a second hypothesis:

H2: LMX is significantly correlated with workers' internal service behavioural intention and its causes.
The interactions with supervisors and co-workers often affect the job morale of the frontline workers, which in turn affects service quality (Young and Corsun, 2009; Chiang and Hsieh, 2012). Susskind, Kacmar, and Borchgrevink (2007) used the restaurant workers as research subjects and found that these workers delivered high quality service when they perceived mutual assistance and support among co-workers. Guchait, Pasamehmetoglu, and Dawson (2014) also used restaurant workers as research subjects and found that when these workers perceived mutual assistance and support among co-workers, they experience a sense of security that in turn improved service performance. Workers who made mistakes in providing service fixed them as quickly as possible. Yang (2010) investigated the causes and effects of job satisfaction of workers in the hospitality industry and found that establishing job satisfaction using social exchange affected workers' investment in the job and their willingness to support each other. The service model of the hotel industry requires teamwork and mutual assistance and support among members (Chen, 2013). Workers need to establish friendly and reciprocal relationships with both managers and co-workers to provide services that meet or exceed customer expectations. Thus, we proposed a third hypothesis:

H3: Co-worker exchange is significantly correlated with workers' internal service behavioural intention and its causes.

The conceptual framework of this study is illustrated in Figure 1.

\section{Methodology}

In this study, a questionnaire survey was used to investigate the effect models of LMX, co-worker exchange, and internal service behavioural intention for service personnel in the domestic hospitality industry. We used an LMX questionnaire and a co-worker exchange questionnaire that was developed by Ma and Qu (2011), each of which consisted of 6 questions. We used the TPB questionnaire of Beck and Ajzen (1991) to develop questions related to attitude, subjective norms, perceived behavioural control, and internal service behavioural intention, each of which included 7, 3, 3, and 3 items, respectively, for a total of 16 items. We presented a preliminary questionnaire to 5 scholars and professionals in the industry to evaluate the appropriateness of the questionnaire, and modified the language and narrative of the questionnaire such that the questionnaire could be used to measure all the variables 


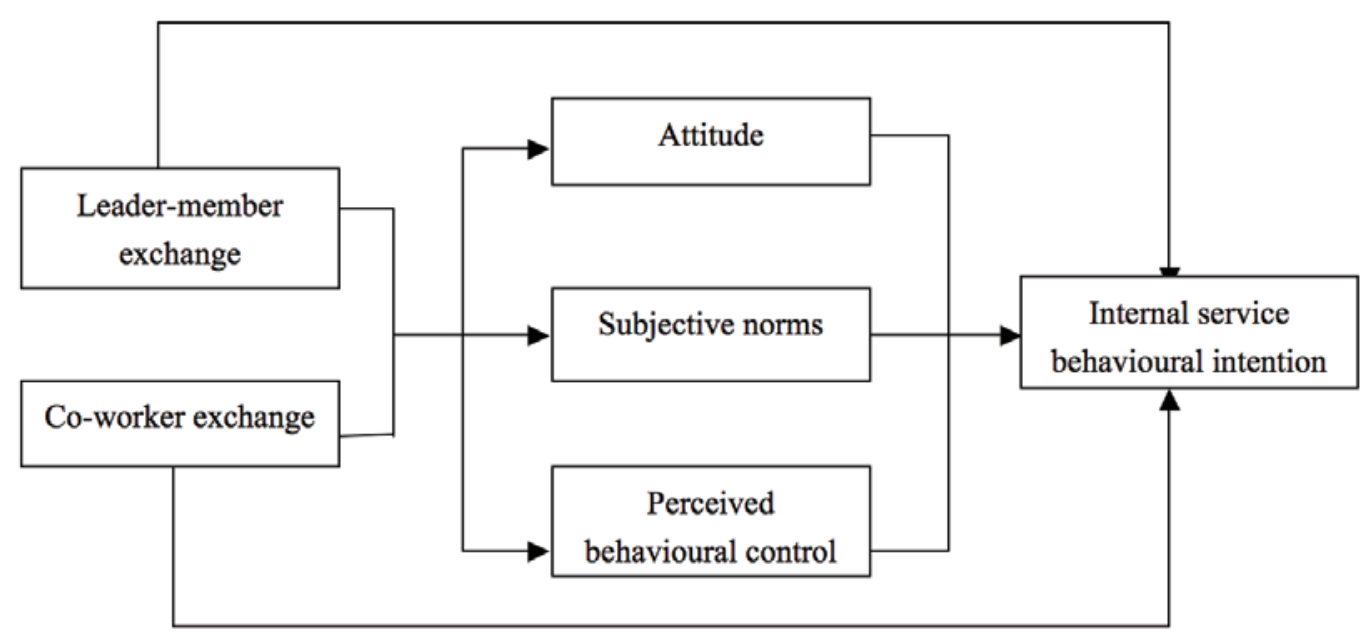

Figure 1: Research Framework

in this study. The formal questionnaire that was used in this study consisted of 4 sections. In the first section consisting of 12 questions, the workers were asked about their perception of their hotel managers and co-workers; in the second section consisting of 16 questions, workers were asked about their perception of their co-workers' internal service. In both sections, a Likert 5-point scale was used to describe the degree of agreement, that is, strongly disagree, disagree, neutral, agree, and strongly agree. The third section asked the basic information about the interviewees, including demographic variables such as gender and age.

According to statistics provided by the Taiwan Ministry of Transportation and Communication in the Bureau of Tourism, there are 68 international tourist hotels in Taiwan. We contacted the senior managers of these hotels, and a total of 30 hotels were willing to participate in the questionnaire survey. In this study, we interviewed the frontline service personnel at these 30 international tourist hotels, including personnel at front desks, in service centres, in housekeeping, and in restaurants. We conducted the survey from April to July 2015. We sent out 900 questionnaires and collected 711 questionnaires. After eliminating 27 questionnaires, in which over 5 questions were missing, we collected a total of 684 valid questionnaires (the valid return rate was $76.0 \%$ ). We used validity analysis, correlation analysis, analysis of variance, and regression analysis to investigate the correlations among LMX, co-worker exchange, internal service behavioural intention and its causes, and also verified the framework and hypotheses of this study.

\section{Results}

Females accounted for $57.8 \%$ of the 684 interviewees. The majority $(66.4 \%)$ of the interviewees were between 21 and 39. A large percentage $(59.7 \%)$ of the interviewees had college degrees. Singles accounted for $63.2 \%$ of the interviewees. The highest percentage (39.7\%) of the interviewees had 3 years or less experience in the hotel industry, and the second highest percentage $(24.4 \%)$ of the interviewees had 4 to 6 years of experience. The highest percentage $(44.9 \%)$ of the interviewees had average monthly incomes between NT $\$ 20,000$ and NT\$40,000, and the second highest percentage (33.5\%) of the interviewees had average monthly incomes between NT\$40,000 and NT $\$ 60,000$. The interviewees were distributed among the following departments: the highest percentage was in housekeeping (32.8\%), and the second and third highest percentages were in rooms division $(28.6 \%)$ and the restaurant $(27.9 \%)$, respectively. The highest percentage $(40.8 \%)$ of the interviewees worked in the North, and the second highest (26.5\%) worked in the central region.

After recovering the questionnaires, reliability analysis and confirmatory factor analysis were used to check the reliability and validity of the test questions. As shown in Table 1, the SMC of the questions concerning the research variables is more than 0.61 (between 0.61 and 0.89 ) and the CR is more than 0.81 (between 0.81 and 0.90 ), indicating good internal consistency. In accordance with prior research, if $\chi 2 /$ d.f. $<5$, RMSEA $<.08$, SRMR $<.1$, GFI $>.9$, AGFI $>.8$, and CFI $>9$, the model is considered to be a good fit (Podsakoff, Mackenzie, and Podsakoff, 2012). All 
research variables were found to conform to these standards, and the factor loadings of all questions were as expected, demonstrating the fitness of the overall model. Hair, Black, Babin, and Anderson (2010) suggested that factor loading $>0.5, \mathrm{SMC}>0.5, \mathrm{CR}>0.7$, and AVE $>0.5$ indicated that the constructs have convergent validity. If the square root value extracted from the average variability of latent variables is bigger than the correlation coefficient under a different construct, then the correlation between the latent constructs is weaker than the correlation within the latent constructs. This rule is helpful for evaluating the convergent and discriminant validity of the research variable constructs. The results indicate that the factor loadings of the questions concerning the research variables are all greater than 0.66 (between 0.66 and 0.84 ), SMC $>0.61$ (between 0.61 and 0.89), CR>0.81 (between 0.81 and 0.90), and AVE $>0.56$ (between 0.56 and 0.74), so this model has good convergent validity. In addition, the AVE square root values of all research variables are larger than the correlation coefficients between the constructs, so the model has good discriminant validity.

As shown in Table 1, 'co-worker exchange' has the highest average score in the two social exchanges. 'Attitude' has the highest average score in the internal service behavioural intention dimensions. 'Internal service behavioural intention' has the highest average score among all of the variables.

We used correlation analysis to determine the relationships among LMX, co-worker exchange, internal service behavioural intention, and its causes (Table 2). First, we found that the internal service behavioural intention had a significant positive correlation with the internal service behavioural intention and its causes. Among these variables, the most significant correlation was found between internal service behavioural intention and attitude, and the least significant correlation was found between internal service behavioural intention and subjective norms. Next, we found that LMX had a significant positive correlation with all of the other variables. LMX was most significantly correlated with co-worker exchange. Among the correlations between LMX and various aspects of internal service behavioural intention, LMX was most significantly correlated with attitude. Finally, we found that co-worker exchange had a significant positive correlation with all of the other variables and was most significantly correlated with attitude. However, analysing the correlations among the causes of internal service behavioural intention (i.e., attitude, subjective norms, and perceived behaviour control), LMX, and co-worker exchange showed that in addition to the relatively significant correlation between attitude and co-worker exchange, both subjective norms and perceived behavioural control had a relatively significant correlation with LMX.

Through analysis of variance, this research found that demographic information including age $(\mathrm{F}=3.75 ; \mathrm{p}=0.01)$, marriage $(F=3.78 ; p=0.01)$, seniority $(F=4.43 ; p=0.00)$, and personal monthly income $(\mathrm{F}=5.63 ; \mathrm{p}=0.00)$ have a significant effect on the internal service behavioural intention. Therefore, they were applied as control variables

Table 1: Description and confirmatory factorial analysis on the study variables

\begin{tabular}{lllllllll}
\hline Construct \& Factor & Items & Mean & S. D. & $\begin{array}{l}\text { Factor } \\
\text { Loading }\end{array}$ & Cronbach' $\alpha$ & SMC & CR & AVE \\
\hline $\begin{array}{l}\text { Leader-member } \\
\text { exchange }\end{array}$ & 6 items totally & 4.07 & .58 & $.71-.79$ & .84 & $.70-.85$ & .86 & $.56(.75)$ \\
\hline $\begin{array}{l}\text { Co-worker exchange } \\
\text { 6 items totally }\end{array}$ & 4.17 & .52 & $.66-.74$ & .80 & $.61-.83$ & .81 & $.58(.76)$ \\
\hline $\begin{array}{l}\text { Attitude } \\
\text { Subjective norms }\end{array}$ & 7items totally & 4.20 & .52 & $.67-.74$ & .83 & $.63-.86$ & .84 & $.64(.80)$ \\
\hline $\begin{array}{l}\text { Perceived behavioural } \\
\text { control }\end{array}$ & 3 items totally & 4.13 & .60 & $.78-.84$ & .74 & $.62-.85$ & .90 & $.71(.84)$ \\
\hline $\begin{array}{l}\text { Internal service } \\
\text { behavioural intention }\end{array}$ & 3 items totally & 4.26 & .57 & $.77-.82$ & .71 & $.64-.87$ & .86 \\
\hline
\end{tabular}

Note: () means squared root of AVE 
to determine the power of exchanges to explain internal service behavioural intention.

Using hierarchical regression analysis (see Table 3), we found that age, the number of years of work experience, and monthly income had significant explanatory power on internal service behavioural intention. In addition, after controlling the effects of personality traits, we found that both LMX and co-worker exchange significantly affected the internal service behavioural intention, of which the effects of co-worker exchange were more significant. After controlling the effects of personality traits on LMX and co-worker exchange, we found that all the causes of internal service behavioural intention, namely, the attitude, subjective norms, and perceived behavioural control, significantly affected the internal service behavioural

Table 2: Correlation analysis of the research variables

\begin{tabular}{|c|c|c|c|c|c|c|}
\hline & $\begin{array}{l}\text { Leader-member } \\
\text { exchange }\end{array}$ & $\begin{array}{l}\text { Co-worker } \\
\text { exchange }\end{array}$ & Attitude & $\begin{array}{l}\text { Subjective } \\
\text { norms }\end{array}$ & $\begin{array}{l}\text { Perceived } \\
\text { behavioural } \\
\text { control }\end{array}$ & $\begin{array}{l}\text { Internal service } \\
\text { behavioural } \\
\text { intention }\end{array}$ \\
\hline $\begin{array}{l}\text { Leader-member } \\
\text { exchange }\end{array}$ & 1.00 & & & & & \\
\hline Co-worker exchange & $.70 \star \star$ & 1.00 & & & & \\
\hline Attitude & $.64^{\star \star}$ & $.66^{\star \star}$ & 1.00 & & & \\
\hline Subjective norms & $.59^{\star \star}$ & $.56^{\star \star}$ & $.60 * \star$ & 1.00 & & \\
\hline $\begin{array}{l}\text { Perceived behavioural } \\
\text { control }\end{array}$ & $.57^{\star \star}$ & $.54^{\star \star}$ & $.61 * \star$ & $.54^{\star \star}$ & 1.00 & \\
\hline $\begin{array}{l}\text { Internal service } \\
\text { behavioural intention }\end{array}$ & $.54^{\star \star}$ & $.55^{\star \star}$ & $.59^{\star \star}$ & $.52^{\star \star}$ & $.58^{\star \star}$ & 1.00 \\
\hline
\end{tabular}

${ }^{*}$ means $\mathrm{p}<.05,{ }^{* *}$ means $\mathrm{p}<.01$

Table 3: Hierarchical regression analysis on the effect of leader-member exchange, co-worker exchange, internal service behavioural intention's cases on internal service behavioural intention

\begin{tabular}{|c|c|c|c|c|c|c|c|c|c|c|}
\hline \multirow{2}{*}{\multicolumn{2}{|c|}{$\begin{array}{l}\text { Model Variable } \\
\text { (Dependent Variable: Internal service } \\
\text { behavioural intention) }\end{array}$}} & \multirow{2}{*}{\multicolumn{3}{|c|}{$\begin{array}{l}\text { Level } 1 \\
\text { Personal Basic Data Variable } \\
\text { Beta t p }\end{array}$}} & \multicolumn{3}{|c|}{$\begin{array}{l}\text { Level } 2 \\
\text { Exchanges Variable }\end{array}$} & \multicolumn{3}{|c|}{$\begin{array}{l}\text { Level } 3 \\
\text { Internal Service Behavioural } \\
\text { Intention's Cases Variable }\end{array}$} \\
\hline & & & & & Beta & $\mathbf{t}$ & p & Beta & $\mathbf{t}$ & $\mathbf{p}$ \\
\hline \multirow{9}{*}{ 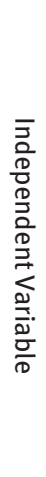 } & Age & -.12 & -1.83 & .07 & -.07 & -1.22 & .23 & -.03 & -.52 & .60 \\
\hline & Marriage & .06 & 1.27 & .20 & .01 & .30 & .76 & .02 & .50 & .62 \\
\hline & Seniority & .15 & 2.14 & .03 & .07 & 1.25 & .21 & .03 & .54 & .59 \\
\hline & Personal monthly income & .12 & 2.30 & .02 & -.04 & -.80 & .42 & -.07 & -1.61 & .11 \\
\hline & Leader-member exchange & & & & .31 & 6.81 & .00 & .10 & 2.14 & .03 \\
\hline & Co-worker exchange & & & & .33 & 7.31 & .00 & .15 & 3.21 & .00 \\
\hline & Attitude & & & & 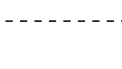 & . & & .20 & 4.42 & .00 \\
\hline & Subjective norms & & & & & & & .14 & 3.38 & .00 \\
\hline & Perceived behavioural control & & & & & & & .26 & 6.51 & .00 \\
\hline \multirow{6}{*}{$\begin{array}{l}3 \\
0 \\
0 \\
0 \\
0 \\
n \\
5 \\
3 \\
3 \\
0 \\
2 \\
2\end{array}$} & $\mathrm{R}^{2}$ & .042 & & & .351 & & & .462 & & \\
\hline & $\mathrm{F}$ & 6.92 & & & 57.31 & & & 60.54 & & \\
\hline & $\mathrm{p}$ & .00 & & & .00 & & & .00 & & \\
\hline & $\Delta \mathrm{R}^{2}$ & .042 & & & .309 & & & .112 & & \\
\hline & $\Delta \mathrm{F}$ & 6.92 & & & 151.56 & & & 43.87 & & \\
\hline & $\Delta \mathrm{p}$ & .00 & & & .00 & & & .00 & & \\
\hline
\end{tabular}


intention, of which the effects of perceived behavioural control were the most significant.

\section{Conclusion}

In this study, we found that attitude, subjective norms, and perceived behavioural control were all significantly positively correlated with internal service behavioural intention, of which the effects of perceived behavioural control were most significant. Thus, we confirmed the first hypothesis of this study (i.e., attitude, subjective norms, and perceived behavioural control of hotel service personnel affects the internal service behavioural intention). Next, we used regression analysis to find that both LMX and co-worker exchange significantly affected the internal service behavioural intention, of which the effects of co-worker exchange was the most significant. Thus, we confirmed the second hypothesis (LMX has significant correlations with workers' internal service behavioural intention and its causes) and the third hypothesis (co-worker exchange is significantly correlated with workers' internal service behavioural intention and its causes) of this study.

In the TPB that was developed by Ajzen (1985), the perceived behavioural control and behavioural intention are both predictable behaviours. The behavioural intention is determined by the individual's attitude, subjective norms, and perceived behavioural control. That is, the more favourable is an individual's attitude toward subjective norms of certain behaviour, the higher is the perceived behavioural control, and the stronger is the individual's desire to demonstrate such behaviour (Ajzen, 1985, 1991). The results of this study support the premise of TPB. We found that it was more likely to observe internal service behavioural intention when surveyed workers assisted co-workers or provided services that their co-workers needed with an accepting and positive attitude; when they believed that important people (such as managers) would consider assisting co-workers as a positive contribution, and considered that they themselves had sufficient ability and resources to assist co-workers and provide the service co-workers that needed. We also observed that the most significant effects on internal service behavioural intention were obtained when workers were confident in providing internal service or realized that they had sufficient resources to provide internal service.

In the social exchange theory, establishing and maintaining positive relationships between interacting parties can encourage the beneficiary to give back, which enables the members in such an exchange to benefit from the relationship (Kamdar and Van Dyne, 2007). Li, Sanders, and Frenkel (2012) and Kim, O'Neill, and Cho (2010) conducted research studies on the hospitality industry and found that leaders who voluntarily provided service and assistance to encourage returns or positive responses from subordinates positively stimulated workers' investment in the jobs and their willingness to assist and support each other. Yang (2010) investigated the causes and effects of job satisfaction for workers in the hospitality industry and found that using social exchange to establish work satisfaction affected the workers' investment in the job and their willingness to support each other. The results of the present study support the views of Guchait, Pasamehmetoglu, and Dawson (2014); Li, Sanders, and Frenkel (2012); Kim, O’Neill, and Cho (2010); and Yang (2010). We found that LMX and co-worker exchange, both positively affected the hotel workers' internal service behavioural intention. When workers perceived assistance and support from co-workers, they were especially willing to give back and support each other. The results of this study have managerial value and implications for the hospitality industry, which is faced with competition, diversification of customer demands, and a rapidly changing environment. Thus, internal service involving teamwork and mutual assistance is necessary to provide quality customer service and work behaviour that is not limited by organizational rules but rather involves the active provision of service that meet customer demands.

This study makes four primary contributions. First, because the hospitality industry relies highly on teamwork, we primarily considered TPB with knowledge sharing as its subject and applied the concept of internal service to the field of hotel service. Next, we developed a correlation model among LMX, co-worker exchange, and internal service behavioural intention that was based on studies in the literature. Third, we found that the TPB could be applied to the field of hotel service and that perceived behavioural control affected the internal service behavioural intention more significantly than the other causes of behavioural intention. Therefore, we recommend that hotel managers establish mechanisms to help workers demonstrate internal service behaviour, such as employee rewards, connecting promotion to internal service behaviour, presenting public awards for internal service behaviour, and announcing support for internal service behaviour. For workers to voluntarily or actively assist or support their co-workers, senior managers must clearly support such behaviour or establish specific rules and incentives to motivate workers to learn about the managers' interest in and recognition of the internal service behaviour, mutual support, and a cooperative 
atmosphere. When senior managers show workers that internal service behaviour will benefit their work, workers will become willing to demonstrate internal service behaviour. Fourth, we found that co-worker exchange was the social exchange factor with the most explanatory power for internal service behavioural intention. Thus, we recommend that hotel managers use communication and delegation to conduct worker performance evaluations that are primarily based on team performance, allow workers to form a mutual support and assistance work model and culture, and encourage workers' internal service behaviour further.

We have three recommendations for future studies. First, the subjects of this study were primarily frontline professional personnel in international tourist hotels, such as personnel at the front desk, in the service centre, in housekeeping, and in the restaurants. Individuals are often unwilling to demonstrate internal service behaviour because of personality factors or self-interest. Thus, researchers that are investigating the factors that encourage workers' internal service behaviour, especially that which motivates workers to assist and support each other, must consider workers' opinions and views, as well as those of managers at other levels, such as departmental managers or senior managers. Thus, we recommend that other types of research subjects are considered in future studies. Second, in this study, we only used social exchange theory to consider the effects of LMX and co-worker exchange on internal service behaviour. However, the factors that stimulate worker behaviour produce a complex relationship network. Thus, we recommend that other managerial or organizational factors, such as the organizational culture and the management style, be considered in future studies. Finally, we applied the TPB and the concept of internal service to hotel service in this study. However, there are various types of hotel service, such as tourist hotels, business hotels, or even home stays. Given the different types and characteristics of service, we recommend that different types of hotels are considered in future studies to develop an effect model of internal service behaviour in the hospitality industry that has more explanatory power.

\section{References}

[1] Ajzen, I. (1985). From intentions to actions: A theory of planned behavior. In J. Kuhl and J. Beckmann (eds.), Action-control: From cognition to behavior. Heidelberg: Springer, 11-39

[2] Ajzen, I. (1991). The theory of planned behavior. Organizational Behavior and Human Decision Processes, 50, 179-211
[3] Bauer, T.N., \& Green, S.G. (1996). Development of leadermember exchange: A longitudinal test. Academy of Management Journal, 39, 1538-1567

[4] Beck, L., \& Ajzen, I. (1991). Predicting dishonest actions using the theory of planned behavior. Journal of Research in Personality, 25(3), 285-301

[5] Bettencourt, L.A., \& Brown, S.W. (1997). Contact employees: Relationships among workplace fairness, job satisfaction, and prosocial service behaviors. Journal of Retailing, 73, 39-61

[6] Billy, B., Pearl, B.K., Gail, S., \& Skip, S. (2006). Job satisfaction, organizational commitment, and internal service quality: A case study of Las Vegas hotel/casino industry. Journal of Human Resources in Hospitality \& Tourism, 5(2), 37-54

[7] Bock, G.W., Zmud, R.W., Kim, Y.G., \& Lee, J.N. (2005). Behavior intention formation in knowledge sharing: Examining the roles of extrinsic motivators, social-psychological forces, and organizational climate. MIS Quarterly, 29(1), 87-111

[8] Boshoff, C., \& Mels, G. (1995). A cause model to evaluate the relationships among supervision, role stress, organizational commitment and internal service quality. European Journal of Marketing, 29(2), 23-42

[9] Campbell, D.T. (1963). Social attitudes and other required behavior dispositions. In S. Koch (eds.), Psychology: A study of a science. New York: McGraw-Hill, 6, 94-172

[10] Chen, W.-J. (2013). Factors influencing internal service quality at international tourist hotels. International Journal of Hospitality Management, 35, 152-160

[11] Chiang, C.-F., \& Hsieh, T.-S. (2012). The impacts of perceived organizational support and psychological empowerment on job performance: The mediating effects of organizational citizenship behavior. International Journal of Hospitality Management, 31, 180-190

[12] Cho, S., \& Johanson, M. (2008). Organizational citizenship behavior and employee performance: Moderating effect of work status in restaurant employees. Journal of Hospitality and Tourism Research, 32, 307

[13] Conner, M., \& Armitage, C.J. (1998). Extending the theory of planned theory: A review for future research. Journal of Applied Social Psychology, 28, 1429-1464

[14] Dansereau, F., Graen, G., \& Haga, W.J. (1975). A vertical dyad linkage approach to leadership within formal organizations: A longitudinal investigation of the role making process. Organizational Behavior and Human Performance, 13, 46-78

[15] Eagly, A.H., \& Chaiken, S. (1993). The psychology of attitudes. Harcourt Brace Jovanovich College Publisher, Orlando, FL, USA, 1

[16] Eisenberger, R., Fasolo, P., \& Davis-LaMastro, V. (1990). Perceived organizational support and employee diligence, commitment, and innovation. Journal of Applied Psychology, 75, 51-59

[17] Fishbein, M., \& Ajzen, I. (1975). Belief, attitude, intention, and behavior: An introduction to theory and research reading. MA: Addison-Wesley

[18] Fitch, J.L., \& Ravin, E.C. (2005). Willpower and perceived behavioral control: Influences on the intention-behavior relationship and postbehavior attributions. Social Behavior and Personality, 33(2), 105-124

[19] Graen, G., \& Cashman, J. (1975). A role-making model of leadership in formal organizations: A development approach. 
In J.G. Hunt \& L.L. Lawson (eds.), Leadership frontiers. Kent, $\mathrm{OH}$ : Kent State University Press, 143-165

[20] Graen, G., Liden, R.C., \& Hoel, W. (1983). Role of leadership in the employee withdrawal process. Journal of Applied Psychology, 67, 868-872

[21] Guchait, P., Pasamehmetoglu, A., \& Dawson, M. (2014). Perceived supervisor and co-worker support for error management: impact on perceived psychological safety and service recovery performance. International Journal of Hospitality Management, 41, 28-37

[22] Han, H., Hsu, L.-T., \& Sheu, C. (2010). Application of the theory of planned behavior to green hotel choice: testing the effect of environmental friendly activities. Tourism Management, 31(3), 325-334

[23] Hair, J.F., Black, W.C., Babin, B.J., \& Anderson, R.E. (2010). Multivariate data analysis: A global perspective. Pearson, New York, NY

[24] Ilies, R., Nahrgang, J.D., \& Morgeson, F.P. (2007). Leadermember exchange and citizenship behaviors: A meta-analysis. Journal of Applied Psychology, 92(1), 269-277

[25] Johnny, C.F.S., \& Bolloju, N. (2005). Explaining the intensions to share and reuse knowledge in the context of IT service operations. Journal of Knowledge Management, 9(6), 30-41

[26] Kamdar, D., \& Van Dyne, L. (2007). The joint effects of personality and workplace social exchange relationships in predicting task performance and citizenship performance. Journal of Applied Psychology, 92(5), 1286-1298

[27] Kidwell, B., \& Jewell, R.D. (2003). An examination of perceived behavioral control: Internal and external influences on intention. Psychology \& Marketing, 20(7), 625-642

[28] Kim, S., O'Neill, J.W., \& Cho, H.-M. (2010). When does an employee not help coworkers? The effect of leader-member exchange on employee envy and organizational citizenship behavior. International Journal of Hospitality Management, 29(3), 530-537

[29] Large, R.O., \& König, T. (2009). A gap model of purchasing's internal service quality: Concept, case study and internal survey. Journal of Purchasing \& Supply Managementm, 15, 24-32

[30] Li, X., Sanders, S., \& Frenkel, S. (2012). How leader-member exchange, work engagement and HRM consistency explain Chinese luxury hotel employees'job performance. International Journal of Hospitality Management, 31(4), 1059-1066

[31] Liden, R.C., \& Graen, G. (1980). Generalizability of the vertical dyad linkage model of leadership. Academy of Management Journal, 23, 451-465

[32] Ma, E., \& Qu, H. (2011). Social exchanges as motivators of hotel employees' organizational citizenship behavior: The proposition and application of a new three-dimensional framework. International Journal of Hospitality Management, 30, 680-688

[33] Organ, D.W., Podsakoff, P.M., \& MacKenzie, S.B. (2006). Organizational citizenship behavior: Its nature, antecedents, and consequences. Sage, Thousand Oaks, CA
[34] Podsakoff, P.M., Mackenzie, S.B., \& Podsakoff, N.P. (2012). Sources of method biases in social science research and recommendations on how to control it. Annual Review of Psychology, 63, 539-569

[35] Rhodes, R.E., \& Courneya, K.S. (2003). Investigating multiple components of attitudes, subjective norms, and perceived control: An examination of the theory of planned behavior in the exercise domain. British Journal of Social Psychology, 42, 129-146

[36] Sherman, S.J., \& Fazio, R.H. (1983). Parallels between attitudes and traits as predictors of behavior. Journal of Personality, 51, 308-345

[37] Sierra, F.F., \& McQuitty, S. (2005). Service providers and customers: social exchange theory and service loyalty. Journal of Services Marketing, 19(6), 392-400

[38] Susskind A.M., Kacmar, M., \& Borchgrevink, C.P. (2003). Customer service providers' attitudes relating to customer service and customer satisfaction in the customer-service exchange. Journal of Applied Psychology, 88, 179-187

[39] Susskind A.M., Kacmar, M., \& Borchgrevink, C.P. (2007). How organizational standards and coworker support improve restaurant service. Cornell Hotel and Restaurant Administration Quarterly, 48(4), 370-379

[40] Taylor, S., \& Todd, P.A. (1995). Understanding information technology usage: A test of competing models. Information Systems Research, 6(2), 144-176

[41] Terry, D.J., \& O'Leary, J.E. (1995). The theory of planned behavior: The effects of perceived behavior control and self-efficacy. British Journal of Social Psychology, 34, 199-220

[42] Tonglet, M., Phillips, P.S., \& Read, A.D. (2004). Using the theory of planned behavior to investigate the determinants of recycling behavior: a case study from Brixworth, UK. Resources. Conservation and Recycling, 41(3), 191-214

[43] Tsai, W.C., Chen, H.W., \& Cheng, J. W. (2009). Employee positive moods as a mediator linking transformational leadership and employee work outcomes. International Journal of Human Resource Management, 20, 206-219

[44] Wildes, V., \& Parks, S.C. (2005). Internal service quality: Marketing models can help to reduce employee turnover. International Journal of Hospitality \& Tourism Administration, 6(2), 1-27

[45] Wu, C.-M., \& Chen, T.-J. (2015). Psychological contract fulfillment in the hotel workplace: Empowering leadership, knowledge exchange, and service performance. International Journal of Hospitality Management, 48, 27-38

[46] Yang, J.-T. (2010). Antecedents and consequences of job satisfaction in the hotel industry. International Journal of Hospitality Management, 29(4), 609-619

[47] Young, C.A., \& Corsun, D.A. (2009). What a nuisance: controlling for negative affectivity versus personality in hospitality stress research. International Journal of Hospitality Management, 28, 280-288

[48] Yukl, L. (1994). Leadership in organizations (2nd ed.) Englewood Cliffs, NJ: Prentice Hall 